Under the rule that a policy should be read most strongly against those who have chosen its words, ${ }^{26}$ insurance companies should not be allowed to escape liability by the technical argument that unpaid-for clauses are to be read to determine intent. Once the device of reading unpaid-for clauses to limit collision coverage is dismissed, there still remains a sound argument, under present law, for excepting acts of God from the coverage. However, it would be better if, within the clause itself, such accidents were specifically excluded. ${ }^{27}$

that in the Chandler case no accident in reality was involved." Barnard v. Houston Fire \& Casualty Ins. Co., 81 So. 2d 132, 136 (La.App., 1955). The court in Ohio Hardware Mut. Ins. Co. v. Sparks, 57 Ga.App. 830, 834, 196 S.E. 915, 918 (1938), was even more definite when it said that the "tornado was not an accident, but was an act of God."

${ }_{26}$ This is one of the great doctrines of insurance law. Consult 13-14 Huddy, Cyclopedia of Automobile Law $\S 48$ (9th ed., 1931); 13 Appleman, Insurance Law and Practice $\$ 7401$ (1943).

${ }^{27}$ In Providence Washington Ins. Co. v. Proffitt, 150 Tex. 207, 239 S.W. $2 d 379$ (1951), the court recommends such an addition.

\title{
AVAILABIITY OF INJUNCTIVE RELIEF UNDER STATE CIVIL RIGHTS ACTS
}

Though twenty-two states ${ }^{1}$ have enacted "civil rights" legislation," the statutes have clearly failed to achieve the drafters' goal of eliminating overt discriminatory practices. Those statutes which provide for specific relief ${ }^{3}$ make available either a civil action for damages, ${ }^{4}$ a criminal penalty of fine and/or

${ }^{1}$ Cal. Civil Code (Deering, 1949) §§51-54; Colo. Rev. Stat. (1953) §25-1-1; Conn. Gen. Stat. (1949) §8375, amended by Public Acts (1953) No. 326; Ill. Rev. Stat. (1953) c. 38, 1125 et seq.; Ind. Stat. Ann. (Burn's, 1956) $\$ \$ 10-901,10-902$; Iowa Code (1954) $\$ \S 735.1,735.2$; Kan. Gen. Stat. Ann. (1949) §21-2424; Mass. Ann. Laws (1933) c. 272, \$\$92A, 98; Mich. Stat. Ann. (1935, Supp., 1953) \$28.343; Minn. Stat. (1953) \$327.09; Mont. Rev. Codes Ann. (1947, Supp., 1955) \$64-211; Neb. Rev. Stat. (1943) §\$20-101, 20-102; N.H. Rev. Laws (1942) c. $208 \S \S 3,4,6$; N. J. Rev. Stat. (1937, Supp., 1953) $\$ \$ 10: 1-2-10: 1-7$; N. M. Stat. Ann. (1953, Supp., 1955) §49-8-1 et seq.; N. Y. Consol. I. Ann. (McKinney, 1948) Civil Rights, $\$ \$ 40,41$; Ohio Rev. Code (Baldwin, 1953) $\$ \$ 2901.35,2901.36$; Ore. Rev. Stat. (1953) $\$ \S 30.670-30.680$; Pa. Stat. Ann. (Purdon, 1945) tit. 18, \$4654; R. I. Gen. Laws (1938) c. 606, \$\$28, 29, amended by R. I. Acts and Resolves (1952) c. 2958; Wash. Rev. Code (1951) \$9.91.010; Wis. Stat. (1953) \$942.04. The statutes vary widely in their scope and provisions. They are compared in Konvitz, The Constitution and Civil Rights 116-19 (1947); consult also Private Remedies under State Equal Rights Statutes, 44 III. L. Rev. 363 (1949).

2 The acts are largely the outgrowth of the Supreme Court's invalidation of the Federal Civil Rights Act of 1875, 18 Stat. 348 (1875), in the Civil Rights Cases, 109 U.S. 3 (1883). The Act served as the model for much of the subsequent state legislation. Insofar as here relevant it provided: "That all persons within the jurisdiction of the United States shall be entitled to the full and equal enjoyment of the accommodations, advantages, facilities, and privileges of inns, public conveyances on land or water, theaters, and other places of public amusement; subject only to the conditions and limitations established by law, and applicable alike to citizens of every race and color, regardless of any previous condition of servitude."

${ }^{3}$ In Montana and New Mexico no sanctions are specified for violation.

1 California and Oregon. 
imprisonment, ${ }^{5}$ or both. ${ }^{6}$ And though the federal courts have made frequent and effective use of injunctive relief in this area, ${ }^{7}$ the statutes of only one state specifically provide for such relief. ${ }^{8}$ Attempts to secure equitable relief in state courts have usually encountered three major obstacles: first, the maxim that equity will protect property rights but not personal rights; second, the principle that a court of equity will not enjoin the commission of a crime; and third, the canon of statutory construction that a statute creating a new right must be considered as providing the exclusive remedy for its violation. This comment will evaluate these obstacles and will attempt to show that injunctive relief is appropriate and desirable so that full realization of civil rights may be assured.

The limitation of equity jurisdiction to the protection of property rights traces its origin to the well-known dictum of Lord Eldon in Gee v. Pritchard. ${ }^{9}$ That the restriction is basically unsuited to a society which places a high value on the personal rights of the individual is the thrust of most of the scholarly comment ${ }^{10}$ and some expressions of modern judicial opinion. ${ }^{11}$ Its rejection is implicit in the numerous cases where courts have adopted an extremely elastic

5 Connecticut, Iowa, Massachusetts, Nebraska, New Hampshire, New Jersey, Pennsylvania, Rhode Island and Washington.

- Illinois, Kansas, Michigan, Minnesota, New York, Colorado, Indiana, Ohio and Wiscon$\sin$. In the latter four states either recovery of damages or conviction upon an indictment bars prosecution of the other remedy.

${ }^{7}$ Injunctive relief is readily available under the federal Civil Rights Act, Rev. Stat. \$1979, 42 U.S.C.A. $\$ 1983$ (Supp., 1955), which provides that the injured party may obtain redress "in an action at law, suit in equity, or other proper proceeding. ..." [This statute is not to be confused with the Civil Rights Act of 1875, discussed at note 2 supra. The present statutory provision is derived from an act of 1871 which was not affected by the Supreme Court's decision in the Civil Rights Cases.] See, e.g., Clemons v. Board of Education of Hillsboro, 228 F.2d 853 (C.A. 6th, 1956); Dawson v. Mayor and City Council of Baltimore, 220 F.2d 386 (C.A. 4th, 1955); Holmes v. Atlanta, 223 F.2d 93 (C.A. 5th, 1955); Williams v. Kansas City, Mo., 104 F.Supp. 848 (D.C. Mo., 1952); Gonzales v. Sheely, 96 F.Supp. 1004 (D.C. Ariz., 1951); Draper v. St. Louis, 92 F.Supp. 546 (E.D. Mo., 1950).

Ill. Rev. Stat. (1955) c. 38, $\$ \$ 128(a-f)$. Consult Recent Federal and Local Legislation, Civil Rights, 3 U. of Chi. L. Rev. 74, 75 (1935).

2 Swan Ch. 402, 19 Rev.Rep. 87 (1818).

${ }^{10}$ Pound, Equitable Relief Against Defamation and Injuries to Personality, 29 Harv. L. Rev. 640 (1916); Moscovitz, Civil Liberties and Injunctive Protection, 39 Ill. L. Rev. 144 (1944); Leflar, Equitable Prevention of Public Wrongs, 14 Tex. L. Rev. 427, 438 (1936); Walsh, Equitable Protection of Personal Rights, 7 N.Y.U.L.Q. Rev. 878 (1930); Chafee, The Progress of the Law-Equitable Relief Against Torts, 34 Harv. L. Rev. 388, 407 (1921).

" "In reading the decisions holding or stating that equity will protect only property rights, one is struck by the absence of any convincing reasons for such a sweeping generalization.... But in so far as the distinction [between personal and property rights] exists we cannot believe that personal rights recognized by law are in general less important to the individual or less vital to society, or less worthy of protection by the peculiar remedies equity can afford than are property rights." 
definition of "property" rights in order to afford relief." The tenacity of the maxim is not, of course, solely to be explained by the existence of judicial reluctance to discard a cherished rule. More persuasive is the explanation that the personal-property dichotomy has served judges as a useful tool in barring from relief claims which, in their view, do not have a sufficient content of justiciable interest. ${ }^{13}$

But obviously the very existence of civil rights legislation gives expression to the lawmakers' intention of giving legal status to the right of being free from discrimination. Therefore, to refuse protection to this right through use of the maxim, on the basis that it is not sufficiently justiciable, seems unjustifiable.

Though the general doctrine that equity will not act to enjoin the commission of a crime is frequently asserted, ${ }^{14}$ it is clear that courts of equity have enjoined criminal acts ${ }^{15}$ and will continue to do so. Analogous to the broad definition of "property" rights discussed above, courts of equity, as a method of expanding the coverage of equity powers in criminal matters, have given liberal scope to the concept of "public nuisance," a technique also employed by legislatures. For example, in Lineberger v. State ex rel. Beeler, ${ }^{16}$ relying on the concept of "public nuisance," a court of equity granted an injunction prohibiting the unlawful practice of law without a license. ${ }^{17}$ Though the equity concept of public

\footnotetext{
12 E.g., Joyner v. Browning, 30 F.Supp. 512 (W. D. Tenn., 1939) (property in the right to vote and to hold public office); Grand Internat'l Brotherhood of Locomotive Engineers v. Mills, 43 Ariz. 379, 31 P.2d 971 (1934) (property interest in union seniority); Stark v. Hamilton, 149 Ga. 227, 99 S.E. 861 (1919) (property right in the raising of a minor daughter); Internat'l News Service v. Associated Press, 248 U.S. 215 (1918) (property in freshly gathered, published news); Vanderbilt v. Mitchell, 72 N.J.Eq. 910, 67 Atl. 97 (1907) (property right in preventing use of family name by wife's illegitimate child); Ex Parte Warfield, 40 Tex.Crim. Rep. 413, 50 S.W. 933 (1899) (property right in the marriage relationship, injunction granted restraining plaintiff's wife's paramour from visiting or communicating with wife).

${ }_{13}$ Moscovitz, op. cit. supra note 10, suggests, as an illustration of such use of the maxim, the cases where a court which has not yet recognized an individual's right to privacy denies relief for an invasion of this right on the basis of the personal-property right distinction. See Roberson v. The Rochester Folding Box Co., 171 N.Y. 538, 553, 64 N.E. 442, 446 (1902); Chapell v. Stewart, 82 Md. 323, 33 Atl. 542 (1896).

14 Burden v. Hoover, 7 Ill.App.2d 296, 192 N.E.2d 463 (1955); Staub v. Mayor of Baxley, 211 Ga. 1, 83 S.E.2d 606 (1954); Armstrong v. Gibson and Cushman, Inc., 202 Misc. 399, 117 N.Y.S.2d 185 (S. Ct., 1952), appeal dismissed 280 App.Div. 939, 116 N.Y.S.2d 135 (2d Dep't, 1952); Pitman v. State, 234 S.W.2d 436 (Tex.Civ.App., 1950);. State ex rel. Allai v. Thatch, 361 Mo. 190, 234 S.W.2d 1 (1950); Mellman v. Metropolitan Jockey Club, 195 Misc. 121, 89 N.Y.S. 2d 64 (S. Ct., 1949); People ex rel. Barrett v. Fritz, 316 Ill.App. 217, 45 N.E.2d 48 (1942).

${ }^{15}$ E.g., Adams v. Commissioners, 204 Md. 165, 102 A.2d 830 (1954) (unlawful installation of gasoline pumps and tanks); People ex rel. Bennett v. Laman, 277 N.Y. 368, 14 N.E.2d 439 (1938) (unlawful practice of medicine); Ezell v. Ritholz, 188 S.C. 39, 198 S.E. 419 (1938) (illegal practice of optometry). Consult In re Debs, 158 U.S. 564 (1895); United States v. Rosoff, 27 F.2d 719 (C.A. 2d, 1928); State v. McMahon, 128 Kan. 772, 280 Pac. 907 (1929).

${ }^{16} 174$ Tenn. 538, 129 S.W.2d 198 (1939).

${ }^{17}$ Accord: State ex rel. Johnson v. Hash, 144 Neb. 495, 13 N.W.2d 716 (1944); State ex rel. Trampe v. Multerer, 234 Wis. 50, 289 N.W. 600 (1940).
} 
nuisance is not so extremely broad as it once was, ${ }^{18}$ it remains sufficiently viable to facilitate the circumvention, where desirable, of the general doctrine that equity will not interfere in criminal questions.

The determination of whether illegal discriminatory practices should justify an exception to the general doctrine requires examination of the types of criminal behavior that equity has enjoined. It has been suggested that despite doctrinaire pronouncements to the effect that equity will not interfere where a legal remedy is theoretically available, cases where an injunction has been granted reveal, as an underlying factor, inadequate enforcement of technically adequate laws. 19 These are cases where, for example, the "social philosophy which moved the legislature to create the crime is not sufficiently self-evident to move the jury's punishing conscience to a conviction even in the face of open violation of the law."20 In fact, there is some evidence that even those officials entrusted with the enforcement of civil rights legislation may be reluctant to prosecute. ${ }^{21}$ In such a situation it would seem that the equitable remedy is eminently well-suited for obtaining effective enforcement. Though the sanctions of equity may not be adequate to prevent the commission of a major felony, the certainty of a contempt citation is more likely to produce compliance than the mere possibility of facing prosecution or having to respond in damages. In short, the use of the injunction can prevent the possibility that the criminal penalty, through inadequacies in enforcement, may become nothing more than a recurrent license fee.

The question of whether the statutory remedies provided by the various state civil rights acts are to be considered as exclusive, thereby precluding injunctive relief, has been infrequently litigated. In cases involving issues other than that of injunctive relief, courts have tended to construe strictly civil rights acts, finding such legislation to be either in derogation of the common law or penal in nature..$^{22}$ However, in four jurisdictions where the only statutory remedy is

${ }^{28}$ As originally announced in State ex rel. Vance v. Crawford, 28 Kan. 726, 733 (1882), the concept included "every place where a public statute is openly, publicly, repeatedly, continuously, persistently and intentionally violated." More recent decisions have limited this broad sweep. See State v. Barron, 136 Kan. 324, 15 P.2d 456 (1932); State v. Maltby, 108 Neb. 578, 188 N.W. 175 (1922). But see State ex rel. Abbott v. House of Vision-Belgard-Spero, Inc., 259 Wis. 87, 91, 47 N.W.2d 321, 323 (1951), noted in [1953] Wis. L. Rev. 163. (1936).

${ }^{19}$ Leflar, Equitable Prevention of Public Wrongs, 14 Tex. L. Rev. 427, 445-46, 448-59

${ }^{20}$ Ibid., at 460 .

21 Consult Goostree, The Iowa Civil Rights Statute: A Problem of Enforcement, 37 Iowa L. Rev. 242 (1952); compare Konvitz, The Constitution and Civil Rights 124-25 (1947).

22 Brown v. Meyer Sanitary Milk Co., 150 Kan. 931,96 P.2d 651 (1939); Pickett v. Kuchan, 323 Ill. 138, 153 N.E. 667 (1926); Chochos v. Burden, 74 Ind.App. 242, 128 N.E. 696 (1920); Darius v. Apostolos, 68 Colo. 323, 190 Pac. 510 (1920); Cohn v. Goldgraben, 170 N.Y.S. 407 (1st Dep't, 1918); Faulkner v. Solazzi, 79 Conn. 541, 65 Atl. 947 (1907); Rhone v. Loomis, 74 Minn. 200, 77 N.W. 317 (1898); Bryan v. Adler, 97 Wis. 124, 72 N.W. 368 (1897). Contra: Ferguson v. Gies, 82 Mich. 358, 46 N.W. 718 (1890). 
a criminal penalty, the courts have indicated that a civil action for damages will also lie. ${ }^{23}$ And in a number of cases where public bodies have been defendants, the additional remedy of mandamus has been granted. ${ }^{24}$ No clear majority rule has evolved from those cases dealing with injunctive relief.

Only five jurisdictions have considered the specific question of the availability . of an injunction as an additional remedy. The California Supreme Court, in 1947, granted plaintiff, who twice had been ousted from defendant's race track, an injunction forbidding further attempts to eject him. ${ }^{25}$ While limiting its decision to those provisions of the California Code ${ }^{26}$ which prohibit a refusal of admission to one who has purchased a ticket, the court specifically rejected defendant's contention ${ }^{27}$ that the Act, since penal in nature, was to be strictly construed, and held that, the statutory remedies being inadequate, an injunction should issue. In Illinois and New York the complainant has been limited to the statutory remedy, but in neither jurisdiction has the issue been raised before the highest court, and the decisions antedate modern judicial concern for civil rights. Thus, in 1918, an Illinois court refused injunctive relief to a plaintiff who had been denied admission to defendants swimming pool, stating that:

The personal rights [which complainants allege were violated] . . . were given to them by statute, which also provides a remedy for such violation, and they should seek redress in the manner prescribed by the statute and not in a court of equity ${ }^{28}$

${ }^{23}$ Bolden v. Grand Rapids Operating Company, 239 Mich. 318, 214 N.W. 241 (1927) (The Michigan law has since been amended so as to provide specifically for civil recovery of treble the damages sustained.); Anderson v. Pantages Theater Co., 114 Wash. 24, 194 Pac. 813 (1921); Humburd v. Crawford, 128 Iowa 743, 105 N.W. 330 (1905); see Everett v. Harron, 380 Pa. 123, 127, 110 A.2d 383, 386 (1955).

24 Stone v. Pasadena, 47 Cal.App. 2d 749, 118 P.2d 866 (1941); Raison v. Board of Education, 103 N.J.L. 547, 137 Atl. 847 (1927); People ex rel. Peair v. Board of Education, 127 IIl. 613, 21 N.E. 189 (1889).

${ }^{25}$ Orloff v. Los Angeles Turf Club, 30 Cal.2d 110, 180 P.2d 321 (1947).

${ }^{26}$ Cal. Civil Code (Deering, 1949) $\S 53,54$.

${ }^{27}$ Defendant's contention was based on the fact that the Act requires payment of $\$ 100$ in damages in addition to any damages proved. A liberal construction was facilitated by section 4 of the California Code which states: "The rule of the common law, that statutes in derogation thereof are to be strictly construed, has no application to this code ... its provisions are to be liberally construed with a view to effect its objects and promote justice."

28 White v. Pasfield, 212 Ill.App. 73,77 (1918). The court distinguished, without explanation, People ex rel. Peair v. Board of Education, 127 Ill. 613, 21 N.E. 187 (1889), where mandamus had been granted. The Illinois legislature has since provided for injunctive relief under certain circumstances. Consult note 8 supra. An early New York decision had taken the view that a suit for injunctive relief might be maintained. Grannan v. Westchester Racing Ass'n, 16 App.Div. 8, 44 N.Y.Supp. 790 (2d Dep't, 1897), rev'd on other grounds, 153 N.Y. 449, 47 N.E. 896(1897). A subsequent decision, Woolcott v. Shubert, 169 App.Div. 194, 154 N.Y.Supp. 643 (1915), rejected this view, holding the statutory remedies exclusive. The latter case was somewhat of a cause celebre in its day. It involved the refusal of the Messrs. Shubert to admit Mr. Woolcott to performances given in their theatres, on the basis that his drama criticism was objectionable in the extreme. 
Conflicting results have been reached in the only two jurisdictions that have passed upon the issue of injunctive relief since the impact upon civil rights of the monumental Supreme Court Desegregation decision. ${ }^{29}$ In Fletcher v. Coney Island, Inc. ${ }^{30}$ the Ohio Supreme Court, in a five-to-two decision, affrmed the appellate court's reversal of the trial court's grant of an injunction restraining defendant amusement park from denying plaintiff admission because of her race. Disagreeing with the California view that a court of equity could go beyond the statutory remedies if it deemed them inadequate, the court, per Zimmerman, J., stated that the granting of the relief sought would be "to indulge in judicial legislation ... manifestly a task for the General Assembly."

The Pennsylvania Supreme Court has made the strongest argument for the granting of injunctive relief in Everett v. Harron, ${ }^{32}$ unanimously upholding an injunction directing the operators of a swimming pool and recreation park to cease excluding Negroes. The court rejected the contentions that no injunction should issue because a personal right was involved and because a criminal act would be enjoined, pointing out that the maxim limiting equitable relief to the protection of property rights "is a generalization 'more honored in the breach than the observance,' and runs counter to the cardinal need of flexibility in the domain of equity jurisprudence." ${ }^{33}$ And, "[t] plained of is a crime," the court stated, "neither confers equitable jurisdiction nor ousts it." ${ }^{34}$ Rather, the true test, according to the court, is whether the right which is sought to be protected is one of which equity will take cognizance. Relying on the time-honored maxim that "whenever there is a right there is a remedy," the court rejected the argument that the Act's penal sanctions were to be considered exclusive.

The above cases reveal that the decision as to whether civil rights legislation is to be construed narrowly is not dictated by any substantive rules of law. Only in California has the legislature given explicit directions to the courts to construe the legislation liberally..$^{35}$ The canons of statutory construction provide little assistance; though it is said that statutes in derogation of the common law are to be strictly construed, of equal standing is the canon that requires remedial

${ }^{29}$ Brown v. Board of Education, 347 U.S. 483 (1954).

so 165 Ohio 150 , 134 N.E.2d 371 (1956).

${ }^{31}$ Ibid., at 155, 374-75. Ohio's lower courts, with the exception of one trial court decision (Tate v. Eidelman, 32 Ohio N.P. [N.S.] 478 [1934]), had reached different results. Thus, in Gillespie v. Lake Shore Golf Club, Inc., 56 Ohio L.Abs. 222, 91 N.E.2d 290 (1950), the court granted an injunction which required the club to permit Negroes to play on its courses. And in Colbert v. Coney Island, Inc., 97 Ohio L.Abs. 311, 121 N.E.2d 911 (1954), a case growing out of the same series of incidents as the Fletcher case but decided by a different panel of judges, the court, though denying an injunction on the grounds of misjoinder, emphatically stated its belief that the statutory remedy was neither adequate nor exclusive.

32380 Pa. 123, 110 A.2d 383 (1955).

${ }^{34}$ Ibid., at 128 and 386.

${ }^{33}$ Ibid., at 130 and 387.

${ }^{35}$ Consult note 27 supra. 
legislation to receive a liberal construction. ${ }^{36}$ Since the realization has grown in recent years that civil rights deserve the fullest protection that our system of law can offer, there is strong argument for a liberal construction of civil rights legislation that would utilize the most effective available remedies. The words of Judge Weber, the trial judge in the Coney Island case, seem appropriate:

The statute creates a personal right to every citizen to fully enjoy the facilities of a place of public accommodation upon equal terms with every other citizen. It is inconceivable that the legislative purpose was that some should have the opportunity actually to enjoy the facilities of such a place but that others, equally without personal fault, should be compelled to accept from a wrongdoer money as a substitute for such opportunity. ${ }^{37}$

If, then, civil rights statutes are to be liberally construed, statutory remedies need not be considered exhaustive. As has been shown, the maxims restraining injunctive use where personal rights or crimes are involved do not preclude equitable relief; indeed, they are meaningful only when regarded as explanations, rather than as mandates, for judicial decisions.

A number of factors combine to make injunctive relief particularly appropriate to remedy infringement of an individual's civil rights. The traditional basis for the exercise of equity powers is inadequacy of the remedy at law. When criminal enforcement is lax or difficult to obtain, the legal remedy is, for all practical purposes, inadequate. And even when enforcement is adequate, the imposition of a criminal penalty is an unsatisfactory substitute for the actual enjoyment of the rights created by legislation. The award of monetary damages is equally unsatisfactory because of the nature of the personal right infringed. Not only are such damages difficult to assess, they cannot provide full compensation. Another factor of practical importance is the likelihood of a multiplicity of suits at law under those statutes which make a civil action available. Finally, the injunction offers the flexibility needed in dealing with a complex social problem.

${ }^{36}$ For illustrations of the flexibility of the canons of statutory construction consult Llewellyn, Remarks on the Theory of Appellate Decision, 3 Vand. L. Rev. 395 (1950). Professor Ilewellyn points out that "to make any canon take hold in a particular instance, the construction contended for must be sold, essentially, by means other than the use of the canon." Ibid., at 401. Compare Fordham and Leach, Interpretation of Statutes in Derogation of the Common Law, 3 Vand. L. Rev. 438, 448-53 (1950).

${ }^{37}$ Fletcher v. Coney Island, Inc., 54 Ohio O. 112, 121 N.E.2d 574, 582 (1954). 